Ambiente \& Água - An Interdisciplinary Journal of Applied Science
ISSN 1980-993X - doi:10.4136/1980-993X
www.ambi-agua.net
E-mail: ambi-agua@agro.unitau.br

\title{
Land-use effects on river habitat quality and sediment granulometry along a 4th-order tropical river
}

\author{
doi: 10.4136/ambi-agua.1232
}

Received: 28 Oct. 2013; Accepted: 19 Nov. 2013

\author{
Iola Gonçalves Boëchat ${ }^{{ }^{*}}$; Aparecida Beatriz das Mercês de Paiva ${ }^{1}$; \\ Sandra Hille ${ }^{2}$; Björn Gücker ${ }^{1}$ \\ ${ }^{1}$ Federal University of São João del-Rei, São João del-Rei, MG, Brazil \\ Department of Biosystems Engineering \\ ${ }^{2}$ Aarhus University, Silkeborg, Denmark \\ Department of Bioscience \\ * Corresponding author: e-mail: iboechat@ufsj.edu.br, \\ beatrizpaiva12@hotmail.com,shi@dmu.dk,guecker@ufsj.edu.br
}

\begin{abstract}
Land-use change is among the most important human impacts on habitat quality and species diversity. In this study, we investigated the effects of land use on river habitat quality and sediment granulometry in a larger tropical river, affected by urbanization and agricultural land use. We selected 15 representative sampling reaches in the Rio das Mortes basin, 12 of them along the main river from its headwater to its mouth, and 3 in major tributaries. A habitat survey was conducted in these reaches in the dry season 2010 and sediment samples were taken for granulometry analyses. Sub-basin land cover of reaches was dominated by natural vegetation (41.6 to $60.2 \%$ of total land cover), followed by agricultural land cover (38.4\% to $56.9 \%)$ and urban land cover (1.4\% to 5.6\%). Sediments were dominated by poorly to moderately sorted silts to sands, little conducive to diverse biological communities. According to the river habitat survey, all investigated river reaches exhibited moderately to totally disturbed habitat integrity, due to diverse and often co-occurring human impacts, such as riparian deforestation, water abstraction, sand and gravel extraction, and margin erosion. Only one of the investigated sampling reaches exhibited the minimum riparian forest corridor width demanded by the Brazilian Forest Code. Our results indicated that river habitat and sediment quality mainly depended on conditions in the direct vicinity of river reaches. Accordingly, initial cost-effective restoration of aquatic habitats could be achieved by relatively simple channel restoration measures and the protection of the riparian corridor in the investigated tropical river.
\end{abstract}

Keywords: Neotropical rivers, urbanization, agriculture, structural integrity.

\section{Efeitos do uso do solo sobre a qualidade de habitat e a granulometria do sedimento ao longo de um rio tropical de $4^{\text {a }}$ ordem}

\section{RESUMO}

Mudanças no uso e ocupação do solo representam um importante impacto antrópico sobre a qualidade de habitats e a diversidade biológica. Os efeitos do uso do solo sobre a qualidade de habitats e a granulometria do sedimento em um rio tropical impactado por urbanização e agricultura foram investigados. Foram selecionados 15 trechos de amostragem 
representativos da bacia do Rio das Mortes, sendo 12 localizados no leito principal, desde a cabeceira até a foz, e os restantes em três dos principais tributários. Um levantamento de habitat foi realizado nestes trechos durante a estação seca de 2010 e amostras de sedimento foram coletadas para análise granulométrica. A cobertura da bacia nos trechos estudados foi dominada por vegetação natural (41.6 a $60.2 \%$ ), seguida por agricultura (38.4 a $56.9 \%$ ) e urbanização (1.4 a 5.6\%). Os sedimentos foram dominados por silte e areia, pouco favoráveis à diversidade biológica. De acordo com o levantamento de habitat, todos os trechos apresentaram integridade moderada ou totalmente perturbada, devido a diversos impactos frequentes, tais como remoção de mata ciliar, captação de água, extração de areia e cascalho e erosão. Apenas um dos trechos estudados apresentou largura de corredor ripário em concordância com o exigido pelo Código Florestal Brasileiro. Os resultados indicam que a integridade de habitat e a qualidade do sedimento riverinos dependem principalmente das condições presentes na vizinhança imediata dos trechos estudados. Assim, a restauração custo-efetiva dos habitats aquáticos poderia ser alcançada por medidas simples de restauração do canal e a proteção da vegetação ripária neste rio tropical.

Palavras-chave: Rios neotropicais, urbanização, agricultura, integridade estrutural.

\section{INTRODUCTION}

Land-use change, i.e., the transformation of natural land into agricultural and urban area, is among the most important human impacts on biodiversity and ecosystem functioning (Foley et al., 2005; Pereira et al., 2010). Effects of land-use change range from habitat destruction and pollution to extensive modifications of global biogeochemical cycles (Foley et al., 2005). Globally, land-use change affects the global matter cycles, such as the carbon $(\mathrm{C})$, nitrogen $(\mathrm{N})$ and phosphorus $(\mathrm{P})$ cycles, as well as global climate and hydrology (Vitousek et al., 1997; Meir et al., 2006). Moreover, global declines in biodiversity may be largely due to habitat loss, modification and simplification (Pimm et al., 1995; Vitousek et al., 1997). Regionally, nutrient and contaminant pollution of water resources and soils (Carpenter et al., 1998; Allan, 2004), climate change, and altered watershed water budgets are frequently reported impacts (Pielke et al., 2002; Kalnay and Cai, 2003).

Patterns of land-use effects may differ between temperate and tropical watersheds, especially those of urban land use, due to the absence of adequate domestic and industrial sewage treatment, and missing or inefficient municipal land development plans in many tropical countries. Impacts of agricultural land use may also differ owing to differences in soil properties, nutrient availability, geology and climate (Dudgeon, 2008). Pristine tropical soils are often highly weathered and leached, and thus strongly $\mathrm{N}$ and $\mathrm{P}$ limited, making them especially susceptible to eutrophication (Tiessen et al., 2002; Gücker et al., 2009). Additionally, high surface runoff due to intense rainfall frequently causes soil erosion, high suspended sediment loads of running waters, and subsequent sediment deposition in aquatic ecosystems (Dudgeon, 2008). In general, soil erosion of clearcut watersheds in the tropics is higher than in other regions (Hudson, 1971). Agricultural and urban land use is also responsible for more localized erosion types, such as bank erosion at rivers and lakes, and gully erosion, delivering substantial loads of fine sediments to aquatic ecosystems. Associated decreases in stream invertebrate diversity and biomass, as well as impacts on ecosystem functioning have been reported (Wantzen, 2006; Dudgeon, 2008; Gücker et al., 2009).

Monitoring, assessing and understanding the effects of land-use impacts on aquatic habitat quality and diversity, as well on the granulometry and structure of benthic sediments is an important step towards the mitigation and restoration of aquatic systems impacted by human activities (Brauns et al., 2011; Nascimento et al., 2012). In many continental aquatic ecosystems, sediments are the most important habitat for the biotic community (including 
microbes, primary producers, and consumers) and human impacts on sediment quality may have important consequences for aquatic food webs and ecosystem functioning (Wantzen, 2006; Brauns et al., 2011). Therefore, the main objective of this study was to investigate effects of watershed land use on river habitat quality and sediment granulometry in a larger tropical river affected by urbanization and agricultural land use. We expected urbanization and agriculture to adversely affect river habitat and sediment quality, and to be associated with riparian deforestation, erosion and sedimentation.

\section{MATERIALS AND METHODS}

\subsection{Study area}

The investigated tropical watershed is located in the southern part of the Serra do Espinhaço mountain range in the transition zone between the Brazilian Cerrado savanna and the Atlantic rainforest. The region's climate is characterized by warm, rainy summers (September - March) and mild, dry winters (March - September). The soils are sandy and poor in nutrients, rich in iron and manganese and subjected to erosion in areas where the original savanna or semi-deciduous forest vegetation has been removed (Klink and Machado, 2005). The investigated river, the Rio das Mortes, is a $4^{\text {th }}$-order tributary to the Rio Grande in the upper Paraná basin. Land cover in its watershed is mainly native vegetation $(52.0 \%$ of total area), as well as pasture and agriculture (44.4\%), and little urban land cover (3.4\%). We selected 15 sampling reaches in the Rio das Mortes basin, 12 of them along the main river from its headwater to its mouth (Figure 1), and 3 in major tributaries. All reaches represented typical channel and riparian zone characteristics for each sub region of the watershed. A habitat survey was conducted in all reaches in the dry season 2010. Sediment samples were taken in triplicate in each reach, with exception of sampling reach 1 that was subdivided in a pool and a riffle reach, which were then sampled separately.

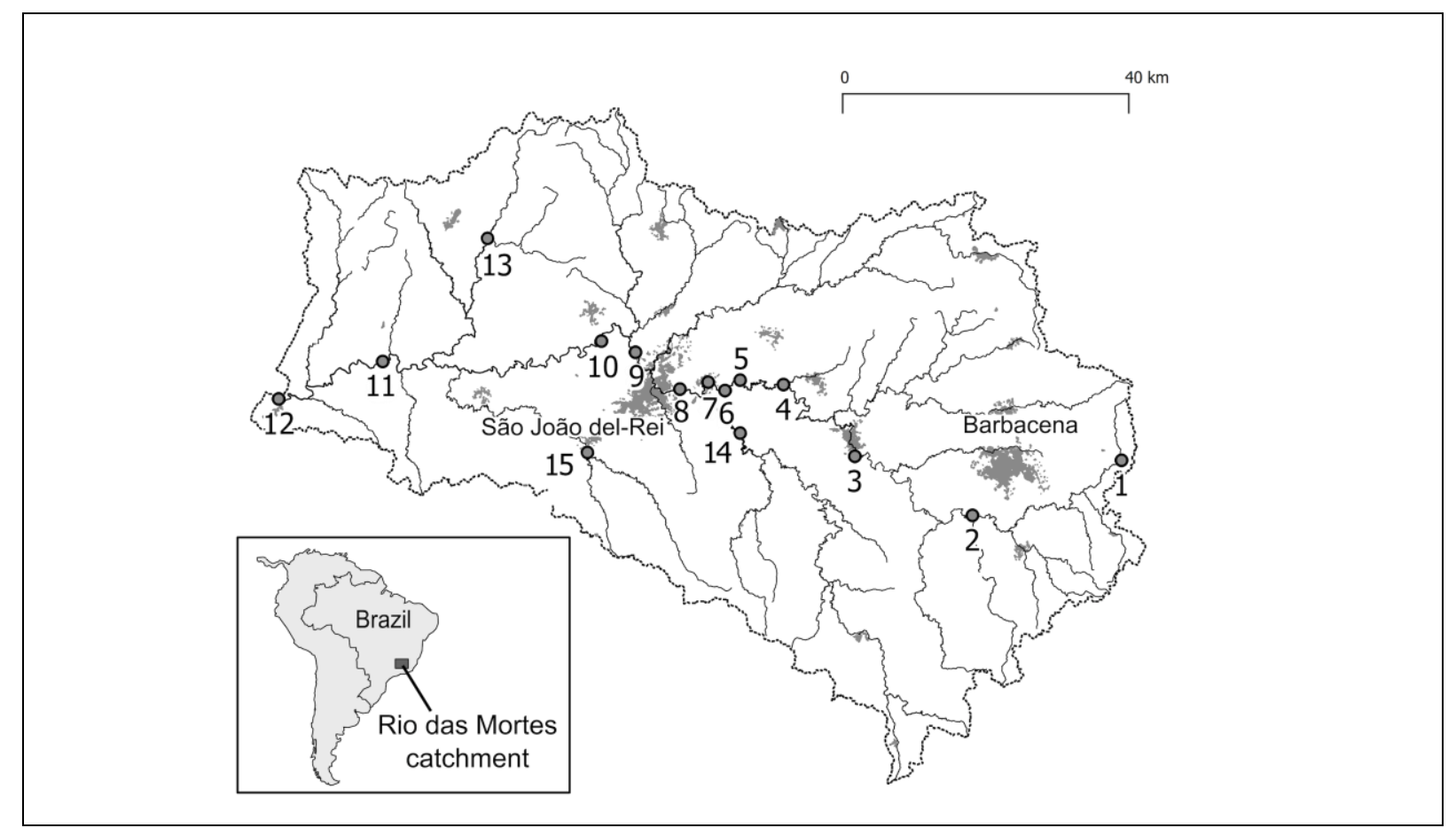

Figure 1: Study sites in the Rio das Mortes watershed. Sites 1 to 12 are situated along the main river; sites 13 to 15 are the tributaries Rio Peixe, Rio Elvas and Pequeno Rio das Mortes, respectively. 


\subsection{Land cover}

We performed a land cover characterization of the entire river basin adopting supervised classification techniques (Silva-Junior et al., 2014). Thereby, 16 land use categories were distinguished (listed at the end of this paragraph). We delimited sub-watersheds upstream of each study reach based on hypsometric maps and land cover distributions for these sub-watersheds were calculated based on the previous land cover characterization. We also delimited a riparian corridor of $300 \mathrm{~m}$ width and $500 \mathrm{~m}$ length for each reach and calculated land cover distributions in these corridors. Land use categories were classified as natural land cover (primary and secondary forest, Cerrado savanna, rupestrian fields, Campo Limpo grassland, rock outcrops and surface waters), agricultural land cover (pasture, crop plantation, open soil, eucalyptus plantation and burnt areas) and urban land cover (mainly urban areas, roads, railways and mining). Contributions of these land use categories were subsequently summed up and the aggregated categories (natural, agricultural and urban land cover) were used in further analyses.

\subsection{Habitat assessment}

We investigated the structural integrity of each study reach using the German river habitat on-site survey methodology (Kamp et al., 2007). Following this methodology, each sampling reach received a score, representing the structural integrity of the river bed, banks and a $100 \mathrm{~m}$ wide floodplain corridor. This habitat assessment method considers six main parameters (longitudinal profile, bank structures, etc.) defined by 14 functional units (sinuosity, constructions, etc.). The final assessment score value varies from 1 (undisturbed condition) to 7 (totally disturbed) (Kamp et al., 2007).

\subsection{Granulometry}

We dried sediment samples for $48 \mathrm{~h}$ at $85^{\circ} \mathrm{C}$ prior to analysis. Mean ( $\left.\pm 1 \mathrm{SD}\right)$ sample dry mass was $265 \pm 113 \mathrm{~g}$. Samples were separately dry-sieved for a minimum of 30 min with an analytical test sieve set (mesh sizes $0.075,0.15,0.3,0.6,1.18,2.36,4.75,6.3,9.5,12.5$, and $25 \mathrm{~mm}$; Bertel, São Paulo, Brazil) until constant weight for each size fraction was achieved. Sediment material for each size fraction was weighed to the nearest $0.01 \mathrm{~g}$ with an analytical balance (Marte AL-500C, São Paulo, Brazil). Thereby obtained sediment particle size spectra were analyzed with the computer program GRADISTAT version 7.0 (Blott and Pye, 2001) using Folk and Ward graphical measures that have proven useful for comparative analyses (Blott and Pye, 2001). We used the Wentworth scale to classify sediments into particle size fractions (Blott and Pye, 2001). Sediments with sorting coefficient intervals of 1.27 to 1.41, 1.42 to $1.62,1.63$ to $2.0,2.01$ to 4 , and 4.01 to 16 were classified as well sorted, moderately well sorted, moderately sorted, poorly sorted, and very poorly sorted, respectively. Skewness intervals of -1.0 to $-0.3,-0.29$ to $-0.1,-0.09$ to $0.1,0.11$ to 0.3 , and 0.31 to 1.0 were used to describe sediments as very fine skewed, fine skewed, symmetrical, coarse skewed, and very coarse skewed, respectively. Kurtosis values of 0.67 to $0.9,0.91$ to 1.11 , and 1.12 to 1.5 were used to describe sediment particle size distributions as platykurtic, mesokurtic, and leptokurtic, respectively.

\section{RESULTS AND DISCUSSION}

\subsection{Land cover}

Sub-watershed land cover of the investigated reaches was dominated by natural vegetation, i.e., 13 of the investigated 15 reaches had more than $50 \%$ natural land cover in their sub-watersheds (Table 1). Contributions of agricultural and urban land cover to total sub-watershed area ranged from $38.4 \%$ to $56.9 \%$, and from $1.4 \%$ to $5.6 \%$, respectively. Land cover in a $300 \mathrm{~m}$ wide and $500 \mathrm{~m}$ long riparian corridor at each sampling reach exhibited a 
wider variability, and contributions of natural, agricultural and urban land cover ranged from $4.2 \%$ to $57.9 \%, 0.4 \%$ to $76.7 \%$, and $18.7 \%$ to $71.5 \%$, respectively.

\subsection{Habitat assessment}

According to the river habitat survey, none of the investigated river reaches exhibited undisturbed or little disturbed conditions (scores 1 and 2, Table 2). The headwater sampling site 1 received score 3 (moderately disturbed), mainly due to partial riparian clearcutting and pasture in the riparian zone, but exhibited high habitat and sediment variability. Two stream reaches received score 4 (clearly disturbed), i.e. the headwater sampling reach 2 with a relatively intact riparian forest and the lower river reach 9 with a high habitat and sediment diversity, and a forest reserve on the right river bank (i.e., the Floresta Nacional de Ritápolis). The remaining 12 sampling reaches, including representative reaches of the river's main three tributaries, received scores ranging from 5 (heavily disturbed) to 7 (totally disturbed), due to diverse and often co-occurring human impacts, such as complete riparian deforestation, water abstraction, sand and gravel extraction, and excessive margin erosion (Table 2). Accordingly, habitat quality of the entire river system can be regarded as considerably disturbed (Kamp et al., 2007). Interestingly, only one of the investigated reaches (headwater reach 2) exhibited the minimum riparian forest corridor, i.e., a protected riparian reserve of $5 \mathrm{~m}$ width, demanded by the Brazilian Forest Code (Nazareno, 2012). Thus, considerable improvements of river habitat quality could already be achieved by landowners respecting prevailing environmental law.

Table 1. Land cover (\% contribution) in the entire watershed upstream of each sampling reach and in a $300 \mathrm{~m}$ wide riparian corridor. Nat $=$ natural, Urb $=$ urban, Agr $=$ agricultural.

\begin{tabular}{|c|c|c|c|c|c|c|}
\hline \multirow[b]{2}{*}{ Reach } & \multicolumn{3}{|c|}{$\begin{array}{l}\text { Watershed } \\
\text { land cover }\end{array}$} & \multicolumn{3}{|c|}{$\begin{array}{l}\text { Riparian } \\
\text { land cover }\end{array}$} \\
\hline & Nat & Urb & Agr & Nat & Urb & Agr \\
\hline 1 & 41.6 & 1.5 & 56.9 & 49.8 & 0.4 & 49.8 \\
\hline 2 & 49.0 & 4.7 & 46.3 & 37.7 & 7.4 & 54.9 \\
\hline 3 & 52.6 & 5.6 & 41.8 & 4.6 & 76.7 & 18.7 \\
\hline 4 & 53.5 & 5.1 & 41.3 & 30.4 & 4.0 & 65.6 \\
\hline 5 & 53.6 & 5.0 & 41.4 & 37.1 & 4.9 & 58.0 \\
\hline 6 & 53.6 & 5.0 & 41.4 & 28.6 & 4.1 & 67.3 \\
\hline 7 & 53.7 & 5.0 & 41.3 & 4.2 & 35.1 & 60.7 \\
\hline 8 & 53.7 & 4.1 & 42.2 & 29.7 & 11.0 & 59.3 \\
\hline 9 & 52.5 & 4.5 & 42.9 & 20.3 & 8.2 & 71.5 \\
\hline 10 & 52.6 & 4.4 & 43.0 & 57.9 & 13.2 & 28.9 \\
\hline 11 & 53.4 & 3.8 & 42.8 & 38.5 & 20.1 & 41.4 \\
\hline 12 & 52.7 & 3.6 & 43.6 & 32.1 & 14.2 & 53.7 \\
\hline 13 & 57.3 & 2.2 & 40.6 & 29.1 & 3.1 & 67.8 \\
\hline 14 & 53.7 & 2.0 & 44.3 & 23.9 & 5.6 & 70.5 \\
\hline 15 & 60.2 & 1.4 & 38.4 & 46.3 & 7.3 & 46.4 \\
\hline
\end{tabular}




\subsection{Granulometry}

The sediments of the Rio das Mortes were dominated by poorly to moderately sorted, silty to sandy sediments (Table 3). Sediments with coarser elements, i.e. ranging from medium sands to gravel were only encountered in five sampling reaches (the two headwater reaches, reach 7 , the forest reserve reach 9 , and the tributary reach 14). Sediment skewness categories ranged from very fine to coarse, but most samples were very fine to fine skewed, potentially indicating fine sediment deposition (Awasthi, 1970). Sediment kurtosis values ranged from very platykurtic to very leptokurtic, indicating variable deviations from normally distributed sediment size. In conclusion, the river's predominantly fine sediments may not be very conducive to diverse biological communities. Coarser sediment elements in more structurally intact river reaches indicate that erosion and subsequent fine sediment deposition may contribute additional fine sediments in many of the more disturbed reaches of the studied river (Nascimento et al., 2012). Accordingly, additional structural elements, such as coarse particulate organic matter, may be especially important for the biotic community and should be a focus of habitat restoration in human-impacted tropical rivers (Acuña et al., 2013). Conversely, massive gravel extraction in the few river reaches exhibiting coarser sediments should be especially deleterious.

Table 2. Structural Integrity Score (SIS) and associated habitat characteristics of the studied river reaches. SIS are 1=undisturbed, 2=little disturbed, 3=moderately disturbed, 4=clearly disturbed, $5=$ heavily disturbed, $6=$ very heavily disturbed, and $7=$ totally disturbed.

\begin{tabular}{l|l|l}
\hline \multicolumn{1}{c|}{ River reach } & SIS & \multicolumn{1}{|c}{ Habitat characteristics } \\
\hline 1 & 3 & $\begin{array}{l}\text { Pasture in the riparian zone and partial riparian } \\
\text { clearcutting; disruptor elements such as bridges } \\
\text { and vicinity to roads; high habitat and sediment } \\
\text { diversity. }\end{array}$ \\
\hline 2 & 4 & $\begin{array}{l}\text { Sewage discharge and vicinity to roads; incised } \\
\text { channel; presence of backwaters; relatively pristine } \\
\text { riparian forest. }\end{array}$ \\
\hline 3 & 6 & $\begin{array}{l}\text { Crop plantation, pasture and buildings in the } \\
\text { riparian zone; margin erosion; natural vegetation } \\
\text { largely removed; solid waste deposition and } \\
\text { sewage discharge, vicinity to roads. }\end{array}$ \\
\hline 4 & 5 & $\begin{array}{l}\text { Vicinity to roads; industrial sediment (sand) } \\
\text { extraction; massive margin erosion and siltation; } \\
\text { relatively pristine forest at right riverbank; dead } \\
\text { wood in the river channel. }\end{array}$ \\
\hline
\end{tabular}




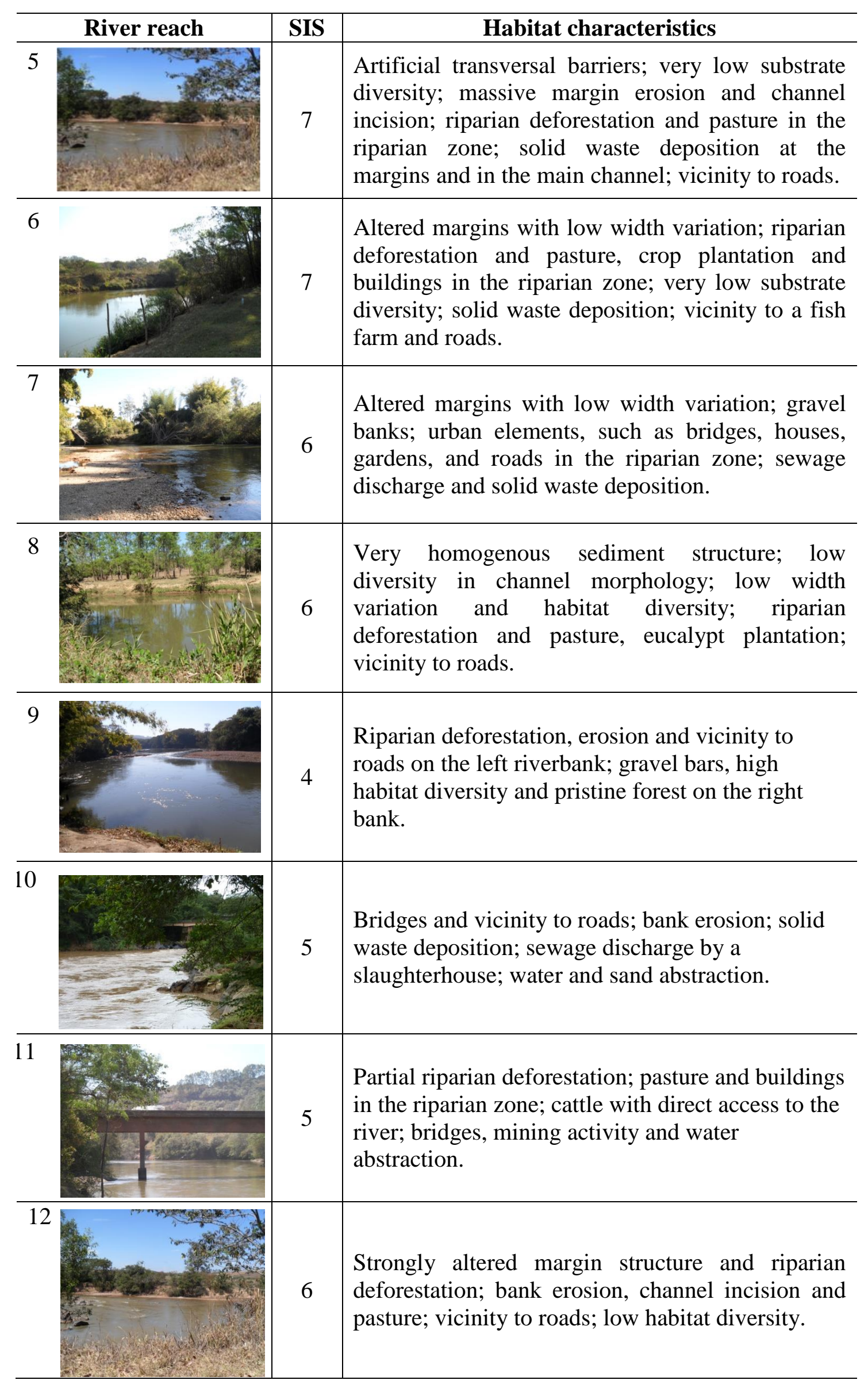




\begin{tabular}{l|l|l}
\hline River reach & SIS & \multicolumn{1}{|c}{ Habitat characteristics } \\
\hline 13 & 7 & $\begin{array}{l}\text { Riparian deforestation, crop plantation and pasture } \\
\text { in the riparian zone; margin erosion; natural } \\
\text { vegetation completely removed; entire riverbed } \\
\text { composed of shifting sands. }\end{array}$ \\
\hline 14 & 7 & $\begin{array}{l}\text { Riparian deforestation, crop plantation and pasture } \\
\text { in the riparian zone; homogeneous fine sediments, } \\
\text { little habitat heterogeneity; water abstraction. }\end{array}$ \\
\hline 15 & 5 & $\begin{array}{l}\text { Partial riparian deforestation; pasture in the } \\
\text { riparian zone. }\end{array}$ \\
\hline
\end{tabular}

Table 3. Sediment classification, mean particle size (MPS), sorting, skewness, and kurtosis of the investigated river reaches.

\begin{tabular}{c|l|r|r|r|c}
\hline Reach & \multicolumn{1}{|c|}{ Sediment classification } & MPS $(\boldsymbol{\mu m})$ & Sorting & Skewness & Kurtosis \\
\hline 1 & Poorly sorted, coarse sand to & $920-$ & $0.9-$ & $-0.3-$ & $-0.5-$ \\
2 & well sorted, medium gravel & 8730 & 2.6 & -2.3 & 1.0 \\
3 & Moderately sorted, medium sand & 259 & 1.8 & 0.0 & 1.0 \\
4 & Poorly sorted, fine sand & 139 & 2.2 & -0.3 & 1.6 \\
5 & Poorly sorted, very fine sand & 96 & 2.4 & -0.4 & 2.3 \\
6 & Poorly sorted, very fine sand & 97 & 2.5 & -0.4 & 2.3 \\
7 & Poorly sorted, very coarse silt & 61 & 3.0 & -0.5 & 1.2 \\
8 & Very well sorted, fine gravel & 6708 & 0.4 & 0.3 & 0.5 \\
9 & Poorly sorted, very coarse silt & 53 & 2.9 & -0.6 & 0.9 \\
10 & Poorly sorted, fine sand & 207 & 3.2 & 0.1 & 1.6 \\
11 & Poorly sorted, very fine sand & 120 & 2.4 & -0.3 & 1.7 \\
12 & Poorly sorted, fine sand & 204 & 2.1 & -0.2 & 1.4 \\
13 & Poorly sorted, coarse silt & 30 & 3.3 & -0.1 & 0.7 \\
14 & Moderately sorted, coarse sand & 549 & 2.0 & 0.2 & 1.1 \\
15 & Moderately sorted, fine sand & 166 & 1.6 & -0.2 & 0.8 \\
\hline
\end{tabular}

\subsection{Relationships between land cover, habitat quality and granulometry}

There were no significant relationships (Spearman correlations, $p>0.1, n=15$ ) between agricultural and urban land use - both in the entire sub-basins and the riparian corridors - and habitat quality or sediment characteristics, with the exception of a positive correlation between urban land cover and sediment kurtosis (Spearman correlation, rho $=0.54, p<0.05$, 
$n=15)$. This correlation may point to an important aspect of the urban stream syndrome (Walsh et al., 2005), i.e., that increased hydraulic stress and increased flash floods in urbanized rivers may lead to more leptokurtic, structurally uniform sediments, thereby affecting the river's biological community. Natural land cover was expected to exhibit a positive relationship with sediment grain size (i.e., more natural land cover leading to coarser sediments) and a negative relationship with the habitat quality score (i.e., more natural land cover leading to better habitat quality), but no such relationships were found, indicating that river habitat and sediment quality only depended on conditions in the direct vicinity of a given river reach. Indeed, a marginally significant negative correlation between natural land cover in the $300 \mathrm{~m}$ riparian corridor and the habitat quality score (Spearman correlation, rho $=-0.47, p=0.07, n=15$ ) supported the view that mostly the riparian zone of the river influenced habitat quality.

\section{CONCLUSIONS}

All river reaches studied in the Rio das Mortes basin exhibited moderately to totally disturbed habitat integrity, due to co-occurring human stressors, such as riparian deforestation, water abstraction, sand and gravel extraction, and margin erosion. Interestingly, only one of the investigated sampling reaches exhibited the minimum riparian forest corridor width demanded by the Brazilian Forest Code. Habitat integrity and sediment characteristics were largely unrelated to whole watershed land cover, but high habitat integrity and coarser sediment elements were restricted to river reaches with a partially intact riparian zone, such as headwater reaches or a reach flanked by a forest reserve. Thus, our results suggest that river habitat and sediment quality mainly depended on environmental conditions in a narrow riparian corridor. Accordingly, initial cost-effective restoration of aquatic habitats could be achieved by relatively simple channel restoration measures and riparian corridor protection in tropical rivers subjected to land-use change.

\section{ACKNOWLEDGEMENTS}

The authors thank F.L. Nascimento, R.C. Chaves, A.P.C. Carvalho, and E.M. Soares for their help with sampling. Two anonymous reviewers are acknowledged for their valuable comments to a first version of the manuscript. This study was supported by the Fundação de Amparo à Pesquisa no Estado de Minas Gerais (FAPEMIG; project number APQ-01609-09).

\section{REFERENCES}

ACUÑA, V.; DÍEZ, J. R.; FlORES, L.; MELEASON, M.; ElOSEGI, A. Does it make economic sense to restore rivers for their ecosystem services? Journal of Applied Ecology, v. 50, n. 4, p. 988-997, 2013. http://dx.doi.org/10.1111/1365-2664.12107

ALLAN, J. D. Landscapes and riverscapes: the influence of land use on stream ecosystems. Annual Review of Ecology, Evolution and Systematics, v. 35, n. 1, p. 257-284, 2004. http://dx.doi.org/10.1146/annurev.ecolsys.35.120202.110122

AWASTHI, A. K. Skewness as an environmental indicator in the Solani river system, Roorkee (India). Sedimentary Geology, v. 4, n. 1, p. 177-183, 1970. http://dx.doi.org/10.1016/0037-0738(70)90010-2 
BRAUNS, M.; GÜCKER, B.; WAGNER, C.; GRACIA, X.F.; WALZ, N.; PUSH, M. T. Human lakeshore development alters the structure and trophic basis of littoral food webs. Journal of Applied Ecology, v. 48, n. 4, p. 916-925, 2011. http://dx.doi.org/10.1111/j.1365-2664.2011.02007.x

BLOTT, S. J.; PYE, K. GRADISTAT: a grain size distribution and statistics package for the analysis of unconsolidated sediments. Earth Surface Processes and Landforms, v. 26, n. 11, p. 1237-1248, 2001. http://dx.doi.org/10.1002/esp.261

CARPENTER, S. R.; CARACO, N. F.; CORRELL, D. L.; HOWARTH, R. W.; SHARPLEY, A. N.; SMITH, V. H. Nonpoint pollution of surface waters with phosphorus and nitrogen. Ecological Applications, v. 8, n. 3, p. 559-568, 1998. http://dx.doi.org/10.1890/1051-0761(1998)008[0559:NPOSWW]2.0.CO;2

DUDGEON, D. Tropical stream ecology. London: Academic Press, 2008. 316 p.

FOLEY, J. A.; DEFRIES, R.; ASNER, G. P.; BARFORD, C.; BONAN, G.; CARPENTER, S. R. et al.. Global consequences of land use. Science, v. 309, n. 5734, p. 570-574, 2005. http://dx.doi.org/ 10.1126/science.1111772

GÜCKER, B.; BOËCHAT, I. G.; GIANI, A. Impacts of agricultural land use on ecosystem structure and whole-stream metabolism of tropical Cerrado streams. Freshwater Biology, v. 54, n. 10, p. 2069-2085, 2009. http://dx.doi.org/10.1111/j.13652427.2008.02069.x

HUDSON, N. W. Soil conservation. Ithaca: Cornell University Press, 1971. 391 p.

KALNAY, E.; CAI, M. Impact of urbanization and land-use change on climate. Nature, v. 423, n. 6939, p. 528-531, 2003. http://dx.doi.org/10.1038/nature01675

KAMP, U.; BINDER, W.; HÖLZL, K. River habitat monitoring and assessment in Germany. Environmental Monitoring and Assessment, v. 127, n. 1-3, p. 209-226, 2007. http://dx.doi.org/10.1007/s10661-006-9274-x

KLINK, C. A.; MACHADO, R. B. Conservation of the Brazilian Cerrado. Conservation Biology, v. 19, n. 3, p. 707-713, 2005. http://dx.doi.org/10.1111/j.15231739.2005.00702.x

MEIR, P.; COX, P.; GRACE, J. The influence of terrestrial ecosystems on climate. Trends in Ecology and Evolution, v. 21, n. 5, p. 254-260, 2006. http://dx.doi. org/10.1016/j.tree.2006.03.005

NASCIMENTO, F. L.; BOËCHAT, I. G.; TEIXEIRA, A. O.; GÜCKER, B. High variability in sediment characteristics of a Neotropical stream impacted by surface mining and gully erosion. Water, Air, and Soil Pollution, v. 223, n. 1, p. 389-398, 2012. http://dx.doi.org/10.1007/s11270-011-0866-x

NAZARENO, A. G. Brazil: combat the effects of forest code changes. Nature, v. 486, n. 7402, p. 191, 2012. http://dx.doi.org/10.1038/486191d

PEREIRA, H. M.; LEADLEY, P. W.; PROENCA, V.; ALKEMADE, R.; SCHARLEMANN, J. P.; FERNANDEZ-MANJARRES, J. F. et al. Scenarios for global biodiversity in the 21st century. Science, v. 330, n. 6010, p. 1496-1501, 2010. http://dx.doi.org/ 10.1126/science. 1196624 
PIELKE, R. A.; MARLAND, G.; BETTS, R. A.; CHASE, T. N.; EASTMAN, J. L.; NILES, J. O. et al. The influence of land-use change and landscape dynamics on the climate system: relevance to climate-change policy beyond the radiative effect of greenhouse gases. Philosophical Transactions of the Royal Society A, v. 360, n. 1797, p. 17051719, 2002. http://dx.doi.org/10.1098/rsta.2002.1027

PIMM, S. L.; RUSSELL, G. J.; GITTLEMAN, J. L.; BROOKS, T. M. The future of biodiversity. Science, v. 269, n. 5222, p. 347-350, 1995. http://dx.doi.org/10.1126 /science.269.5222.347

SILVA-JUNIOR, E. F.; MOULTON, T. P.; BOËCHAT, I. G.; GÜCKER, B. Leaf decomposition and ecosystem metabolism as functional indicators of land use impacts on tropical streams. Ecological Indicators, v. 36, n. 1, p. 195-204, 2014. http://dx.doi.org/10.1016/j.ecolind.2013.07.027

TIESSEN, H.; CUEVAS, E.; CHACON, P. The role of soil organic matter in sustaining soil fertility. Nature, v. 371, n. 6500, p. 783-785, 2002. http://dx.doi.org/10.1038/371783a0

VITOUSEK, P. M.; MOONEY, H. A.; LUBCHENCO, J.; MELILlO, J. M. Human domination of Earth's ecosystems. Science, v. 277, n. 5325, p. 494-499, 1997. http://dx.doi.org/10.1126/science.277.5325.494

WALSH, C. J.; ROY, A. H.; FEMINELLA, J. W.; COTTINGHAM, P. D.; GROFFMAN, P. M.; MORGAN II, R. P. The urban stream syndrome: current knowledge and the search for a cure. Journal of the North American Benthological Society, v. 24, n. 3, p. 706723, 2005. http://dx.doi.org/10.1899/04-028.1

WANTZEN, K. M. Physical pollution: effects of gully erosion on benthic invertebrates in a tropical clear-water stream. Aquatic Conservation: Marine and Freshwater Ecosystems, v. 16, n. 7, p. 733-749, 2006. http://dx.doi.org/ 10.1002/aqc.813 